\title{
Students' Beliefs on Portfolio Assessment
}

\author{
Andrés Canga Alonso \\ University of La Rioja \\ andres.canga@unirioja.es
}

\begin{abstract}
The development of the European Space for Higher Education (ESHE) not only encourages students' active involvement in their learning process, but also promotes formative assessment. Therefore, the aim of this research is to analyse students' beliefs on portfolio assessment in the subject SpanishEnglish/English-Spanish Translation of the degree in English Studies at a university in Spain. A questionnaire was administered at the end of the semester to check learners' views on the implementation of an evaluation system based on portfolios. The results indicate that most of the students involved in the study recognise that using portfolios as assessment tools foster their learning since these learning tools favour reflection on one's own learning as well as revision for the final exam. Contrariwise, learners think that portfolio assembling is time consuming and implies hard work. However, they also feel it is rewarding since they get a better grade at the end of the semester.
\end{abstract}

\section{Introduction}

The developmental process of the European Space for Higher Education (ESHE) has begun in the late 1990's and Spanish universities are still finishing with the adaptation of our degrees to it following the guidance given by the following declarations: Bologna (1999), Prague (2001), Berlin (2003), Bergen (2005) and London (2007). Along with the recommendations posed in the five declarations abovementioned, a new educational principle has also been drawn for universities in order for teaching-language process to 
be more effective based on teachers and learners sharing responsibilities in classroom management and assessment (Fernández Polo and Cal Varela, 2011; Martínez Lirola, 2012b; Roca de Larios and López Serrano, 2011). For the said process to be effective, university should adopt a formative perspective which must pay attention to evaluation as a crucial component of the whole learning process. In this sense, special attention should be paid to new methods of assessment in which the whole grade does not depend on a final mark, as has traditionally happened in Spanish universities, but it should be based on a continuous process (Martínez Lirola and Crespo, 2007; Martínez Lirola, 2008a and b; Pozo Llorente and García Lupión, 2006; Roca de Larios and López Serrano, 2011; Martínez Lirola, 2012a). Moreover, it should not just measure contents but it should concentrate on how students learn, i.e. the different strategies students use to do the proposed tasks and to apply theoretical knowledge to practice (Oxford, 2011). Consequently, students' assessment should be formative, so that teachers can improve their didactic proposals and provide students with certain indications in order improve their learning process. Formative assessment also implies a change in the role of university teachers in the classroom since they become counsellors or assessors who will guide their students throughout their learning process (Benson and Voller, 1997; Cotterall and Crabbe, 1999; Dam, 1995; Little, 1991, 2007, 2009; Sinclair, McGrath and Lamb, 2000; Benson, 2007; Gardner, 2011).

Following a formative assessment at university level implies learner involvement (Little, 2007) since the teacher draws their learners into their own learning process, making them share responsibility for setting the learning agenda, selecting learning activities and materials, managing classroom interaction and evaluating learning outcomes. To achieve these goals, students will require personalised attention from their teachers, which makes it necessary to highlight tutorials (face-to-face or online) so that they become an active part of the students' learning process. In this way, understanding evaluation as a whole implies that attention is paid to supporting students and to correcting students' mistakes during the teaching-learning process, whereas in the traditional evaluation based on just one exam the whole process of students learning and the difficulties in the process were neglected (Brown and Glasner, 1999; Pérez Paredes and Rubio, 2005; Martínez Lirola, 2012a and b).

What is more, learner reflection (Little, 2007) should be emphasized in our teaching programmes since it is very difficult to set a learning target or evaluate learning outcomes without thinking about what you are doing. Learner reflection also requires us to embrace reflective intervention as a key feature of the teaching- learning process. That is, we must supplement the incidental reflection that planning, monitoring and evaluating learning entail by an explicitly detached reflection on the process and content of learning. This reflection is also concerned with the dialogue between teachers and learners or within learner groups. Following Vygotsky's principle of internalisation, what begins as social speech is gradually transformed into the capacity for inner speech in the target language (Vygotsky, 1978).

In short, as Pérez-Paredes and Rubio (2005: 606-607) make clear: "Evaluation considers the teaching and learning program as a whole, and seeks to obtain feedback 
that can serve different purposes for the different agents in education, from teachers to curriculum designers."

From the various ways of evaluation proposed by the European Higher Education Area (EHEA) (see Martínez Lirola and Rubio, 2009: 92), we have chosen portfolios since a portfolio is an evaluation tool that facilitates students' reflective process and also helps them develop certain competences depending on the activities which are included in it (Appel and Shimo, 2004; Barberá, 2005; Fernández Polo and Cal Varela, 2011; Little, 2009; Martínez Lirola, 2012b; Pozo Llorente and García Lupión, 2006; Roca de Larios and López Serrano, 2011).

The concepts of portfolio learning and portfolio assessment are not new (Black and William, 1998; Meeus, Van Looy and Van Petegem, 2006; Wright, Knight and Pomerleau, 1999; Yan, 2003) but its importance has been highlighted after the Council of Europe encouraged the use of the European Language Portfolio (ELP) as an evaluation tool in foreign/second language courses at primary and secondary level (Canga Alonso, 2011; Carson, 2011; Cassany, 2006; Little, 2009; Nunes, 2004). Nevertheless, this document is not intended to be used at tertiary level but there have been scholars that have developed different kinds of portfolios adapting them to the subject in which they were implemented (Fernández Polo and Cal Varela, 2011; Martínez Lirola and Crespo, 2007; Martínez Lirola, 2008, a and b, 2012a and b; Roca de Larios and López Serrano, 2011).

As it was aforementioned, the portfolio is a useful tool in the EHEA because it offers materials that show the students' progress, the grade to which contents have been assimilated and the capacity to develop competences. Specifically, the portfolio allows the integration of the tasks of the learning process within evaluation; secondly it helps to evaluate students' achievements and their degree of maturity and autonomy. Furthermore, it offers teachers more information about the effort students make, and about the different tasks being accomplished. In this way, a portfolio illustrates the whole learning process and reflects how, when and where the different concepts, abilities and competences have been acquired by students. Therefore, a portfolio consists of a folder in which students keep several tasks to accomplish certain objectives and competences selected by teachers.

O'Malley and Valdez Pierce (1996) distinguish between three types of portfolios: showcase, collection and assessment. For the purpose of this paper we will refer to the use of collection and assessment portfolios that include all the tasks, reflections and self-assessments students made during the semester. In order to help students organise and develop their portfolio in such a way that they could observe its usefulness at all stages of the teaching-learning process, Escobar (2001) suggested the following steps:

- To choose tasks according to the main learning objectives and competences.

- To design a pattern of self-evaluation so that students can perform different tasks and evaluate their results.

- To let students select the best tasks and write a report explaining why they have selected them. 
- To evaluate students' tasks according to the criteria that have been previously established and which are known by students and the lecturer.

In light of the reviewed literature, scholars have purported the benefits of portfolio assembling at tertiary level to foster learning and self-assessment. Nevertheless, to our knowledge, there is a scarcity of research focusing on the beliefs learners have about the use of portfolios as effective tools to assess and foster their learning at university (Appel and Shimo, 2004; Fernández Polo and Cal Varela, 2011; Martínez Lirola and Rubio, 2009; Pozo Llorente and García Lupión, 2006). What is more, we have only found one study (Fernández Polo and Cal Varela, 2011) which has looked into students' opinions regarding portfolio implementation in the subject Spanish-English/English-Spanish Translation of the degree in English Studies, as will be the case in our context. For this reason, as will be shown in following sections, our study will focus on learners' views in these two facets.

This said, in following sections we will refer to the methodology we applied as well as to the informants who took part in the present study. Finally, we will present the results attained by the participants.

\section{Methodology}

This section deals with the main methodological principles that frame this research. In order to cover the main aspects dealing with methodology, the section is divided in three sub-sections: participants, research questions and procedure.

\subsection{Participants}

As mentioned in the introduction, this study was carried out on the subject SpanishEnglish/English-Spanish Translation of the degree in English Studies. The course Spanish-English/English-Spanish Translation's main aim is to provide a general overview of translation studies as well as introducing strategies and techniques for the translation of different text typologies (general, literary, tourist or scientific-technical) from Spanish into English and English into Spanish, so that learners will be able to translate texts from Spanish into English and vice versa. It is an optional subject taught in the third year of the degree in English Studies during the second semester. Students had a two-hour session twice a week, which combines theory and practice.

This study comprises 15 responses to a questionnaire (see Appendix 1) which aims at analysing learners' opinions on portfolio usage as a pedagogical and assessment tool.

\subsection{Research questions}

As it was mentioned in the introductory section of this paper, the ESHE and the EHEA promote learner involvement, learner reflection and portfolio assessment as key features 
to foster formative assessment. Therefore, this study aims at answering the following research questions:

1. What do learners think of portfolios as assessment tools in translation learning? (RQ1)

2. Do students have a positive or negative opinion about using portfolios to foster translation learning? (RQ2)

\subsection{Procedure}

The first session of the semester was devoted to explaining the main goals of the subject as well as the different assessment criteria included in the syllabus. This information together with the teaching materials was uploaded to the university website (WebCT) at the beginning of the course. As can be seen in Table 1, portfolio and project work activities included individual and group work tasks.

\begin{tabular}{|c|c|c|c|}
\hline & Tasks & Evaluation system & Percentage \\
\hline Concepts & $\begin{array}{l}\text { - Command of the main concepts } \\
\text { studied during the semester. } \\
\text { - Translation of a text from } \\
\text { English into Spanish. } \\
\text { - Translation of sentences from } \\
\text { Spanish into English. } \\
\text { - Questions on compulsory } \\
\text { readings. }\end{array}$ & $\begin{array}{l}\text { A final test marked } \\
\text { from } 0 \text { to } 6 .\end{array}$ & $60 \%$ \\
\hline $\begin{array}{l}\text { Project Work+ } \\
\text { Portfolio }\end{array}$ & $\begin{array}{l}\text { - Individual work on compulsory } \\
\text { readings. } \\
\text { - Self-assessment } \\
\text { - Self-reflection } \\
\text { - Group work } \\
\text { - Oral presentations }\end{array}$ & $\begin{array}{l}\text { Portfolios should be } \\
\text { handed in at the end of } \\
\text { the semester }\end{array}$ & $40 \%$ \\
\hline
\end{tabular}

Table 1. Evaluation criteria: Translation Spanish-English/English Spanish.

All the activities were selected according to the objectives and competencies pointed out in the syllabus of the subject which aimed at providing students with an ample vision of the field of translation students by getting them actively involved in their learning progress.

Individual activities focused on specific texts on translation studies (book chapters and journal articles) written in English. Students had to read and answer questions about them to improve their communicative competence in the foreign language. Once they finished the task, they had to correct their mistakes using the key provided by the teacher, therefore their learning to learn basic competence was also favoured. All the answers should be word processed to improve their digital competence.

Portfolios should also include an alphabetically ordered list containing the most outstanding terms on the field of translation studies, which appeared in the compulsory readings for each unit in their portfolios. A question about these readings was also 
formulated in the final exam to test students' learning of the aforementioned terms. Thus, communication in the foreign language and digital competence were also favoured. To facilitate term compilation, at the beginning of the term students were given a handout with some guidelines on how to write a definition and they were encouraged to come to tutorials in pairs to discuss the definitions they had provided for the terms included in the first unit. Online tutorials via email or WebCT were also available in order to continuously guide and assess students' work, not only regarding definition of terms but also concerning any of the aspects mentioned in the classroom. Students were also required to reflect on the own learning at the end of each unit by pointing out the most outstanding contents they had learnt and they also had to select the most relevant tasks on practice on translation carried out during the development of the unit. These exercises, which gradually increased their difficulty, focused on different text typologies (i.e. narrative, descriptive, instructional or technical). Selfreflection could be done in the mother tongue, hence learning to learn and communication in the mother tongue and in foreign languages competences were promoted. Nevertheless, most of the documents included in students' portfolios were in English, so some of them decided to use English to perform the task therefore, communication in the foreign language was mostly encouraged.

Learners also worked in groups of three every two units in order to find information about topics related to translation studies and they had to present their findings to their classmates by means of a power point presentation. They were given two in-class sessions to prepare their presentations. Before the presentation, their productions were checked by the teacher in order to provide each group of learners with some feedback. Once their group work results were presented to their classmates a handout containing the most outstanding features of the topic they have dealt which was uploaded to WebCT to make it available for the rest of their partners. Portfolio assembling has a relevant role in students' assessment, being assigned $40 \%$ of the final grade.

\begin{tabular}{|l|l|}
\hline \multicolumn{1}{|c|}{ Task } & \multicolumn{1}{c|}{ Competences } \\
\hline Compulsory readings & Communication in foreign languages \\
- Crystal (1987: 344-349) & Digital \\
- Baker (1998: 277-281) & Self-assessment \\
- Nida \& Reyburn (1981: 5-31) & Learning to learn \\
\hline $\begin{array}{l}\text { Definition of Translation terms } \\
\text { (e.g. Translation, translation studies, descriptive } \\
\text { translation studies) }\end{array}$ & Communication in foreign languages \\
\hline $\begin{array}{l}\text { Practice on translation } \\
\text { (Professing Translation [Baker, 1996]) }\end{array}$ & \\
\hline Group Work: & Communication in foreign languages \\
History of translation & Communication in the mother tongue \\
\hline 5. Self-reflection on your learning progress & Communication in foreign languages \\
& Digital \\
\hline
\end{tabular}

Table 2. Tasks and competences Unit 1: Definition, Nature and Foundations of Translation. 
Table 2 summarizes the aforementioned information on tasks and competences providing an example of the activities carried out by the participants in Unit 1 .

In order to measure students' beliefs in portfolio implementation as a pedagogical and evaluation tool, at the end of the semester a questionnaire adapted from Martínez-Lirola and Rubio (2009) (see Appendix I) was administered. This questionnaire was selected on a twofold basis: on the one hand, our informants were also enrolled in the degree of English Studies, therefore the educational context was quite alike. On the other hand, Martínez Lirola and Crespo's proposal includes general questions which can be applicable to any subject in the aforementioned degree.

The questionnaire was anonymous and consisted of eight questions. These questions aimed at analysing students' opinions on two main grounds: (a) portfolios as assessment tools, and (b) portfolios as instruments to foster learning by implementing an interactive teaching-learning methodology. Students' views on portfolios as evaluation tools were inquired in question 1: "Are you happy having been evaluated with a portfolio? Why?" and Question 4: "Would you recommend a different way of assessing this course? How?" whereas Question 2: "What are the main positive aspects that you observed in the use of a portfolio as a student?" Question 3: "What are the main negative aspects that you observed in the use of a portfolio as a student?" and Question 5: "Do you think that the methodology of this course fosters learning?" focused on portfolios as pedagogical tools to foster learning. Question 5: "Do you think that the methodology of this course has been appropriate? Why?" and Question 7: "What would you change about the methodology of this course?" dealt with learners' opinion on the methodology followed during the semester. A final question: "Would you recommend this course to other students? Justify your answer" was included to see if they had a general positive view about the course by recommending it to other students.

Once explained the main characteristics of the participants involved in the study together with its research goals and the methodology followed, the next section of this paper is devoted to analysing students' answers to the questionnaire by relating their responses to the research questions (see section 2.2) this study focuses on.

\section{Results}

Regarding our first research question (RQ1: What do learners think of portfolios as assessment tools in translation learning?), as shown in figure 1, students were pleased with being evaluated by means of portfolios since $66.7 \%$ answered positively to the question whereas only $26.7 \%$ were against this evaluation criteria and $6.6 \%$ did not provide any answer to the aforementioned question.

As could have been expected students' answers to the question: "Would you recommend a different way of assessing this course? How?" (see figure 2) were also encouraging since $60 \%$ of the informants answered that they would not include any changes in the evaluation criteria. Five students (33.4\%) would change some of these criteria. Thus, three of them suggested different ways to improve course assessment by 
giving less weight to the mark given to portfolio assembling, and including a take-home project for the last week to help with exam preparation. There were only two learners who would remove portfolios from evaluation, as they believed portfolio assembling was a useless time-consuming task. Finally, there was one student who did not answer the question.

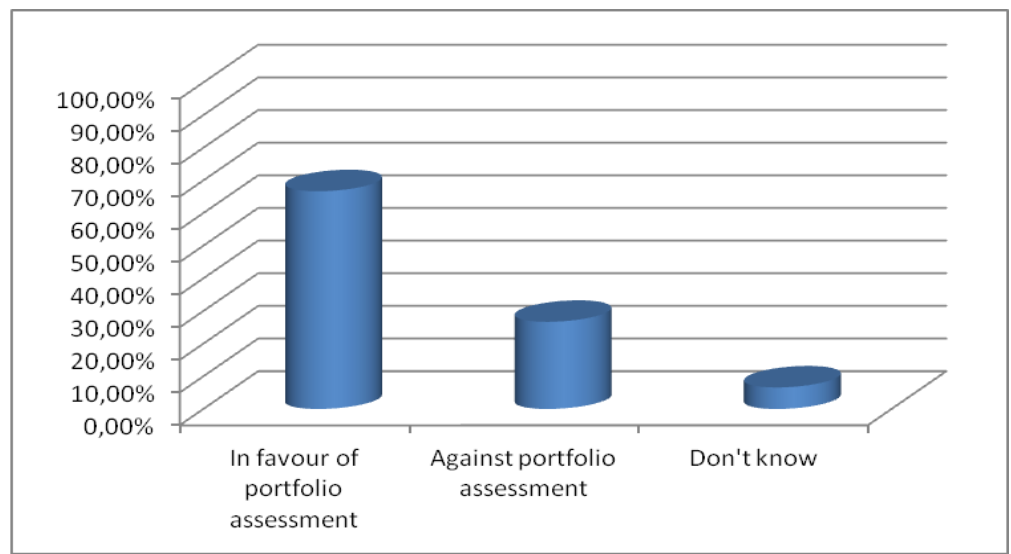

Figure 1. Students' views on portfolio assessment.

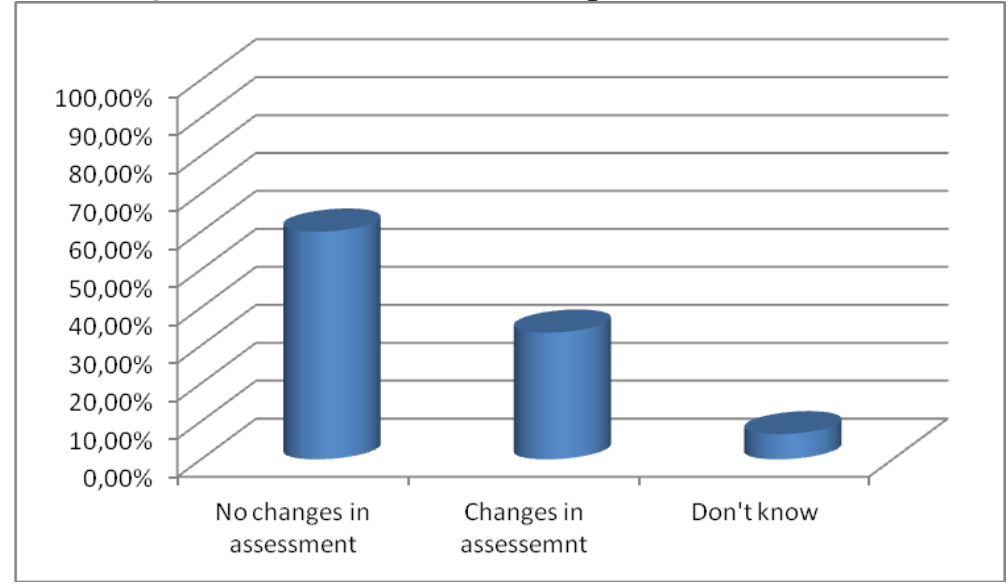

Figure 2. Students' beliefs on evaluation criteria.

As could have been expected students' answers to the question: "Would you recommend a different way of assessing this course? How?" (see figure 2) were also encouraging since $60 \%$ of the informants answered that they would not include any changes in the evaluation criteria. Five students (33.4\%) would change some of these criteria. Thus, three of them suggested different ways to improve course assessment by giving less weight to the mark given to portfolio assembling, and including a take-home project for the last week to help with exam preparation. There were only two learners who would remove portfolios from evaluation, as they believed portfolio assembling was a useless time-consuming task. Finally, there was one student who did not answer the question.

As far as RQ2 (Do students have a positive or negative opinion about using portfolios to foster translation learning?) is concerned, when learners were inquired 
about the most positive and negative aspects in the use of a portfolio as a student (questions 2 and 3), the results indicate that their reaction was positive since only two informants mentioned that it was a waste of time. Nine participants $(60 \%)$ pointed out that portfolios were useful instruments for revision of previous work done during the semester. Two learners believed that portfolios were helpful to study for the final exam, and one thought that they made you aware of the mistakes you made as well as fostered your daily work. Another student mentioned that thanks to the portfolio they could express their thoughts and feelings about the course.

According to our findings, students thought that portfolios' main drawback is that they imply hard work, and are time consuming. Nevertheless, learners considered it was worth compiling them since you could get a better grade at the end of the semester. Lastly, two learners pointed out that the deadline to hand in portfolios should be changed.

As for students' views on the methodology applied during the semester, 93.3\% considered that it was appropriate whereas only one student suggested that more translation practice should have been included in the classroom. All the informants indicated that the methodology implemented fostered translation learning and when asked if they would change anything from the methodology implemented during the semester, seven of them (46.7\%) wouldn't change anything in the future, two learners would include more practice whereas one informant would focus more on theoretical aspects. Finally, one participant would eliminate portfolios from the evaluation system and one student would reduce their length.

In the last question ("Would you recommend this course to other students? Justify your answer") all the participants acknowledged that they would recommend taking the course to prospective students, which seems to show that they were all satisfied with the methodology applied, the assessment criteria followed and the achievement of their learning outcomes throughout the semester.

\section{Discussion}

After analysing the results of our study, overall we have found that most of the participants are satisfied with portfolio assessment. These data resemble those obtained by other researchers in Spain and abroad (Appel and Shimo, 2004; Fernández Polo and Cal Varela, 2011; Martínez Lirola, 2008; Martínez Lirola and Rubio, 2009; Nunes, 2004; Pozo Llorente and García Lupión, 2006). Contrariwise, our findings differ from Roca de Larios and López Serrano (2011), because, at first, their students reacted negatively to portfolio evaluation since they felt insecure as it was an unknown, demanding, and time consuming task. This negative opinion changed as the semester developed and at the end of the course students considered portfolio assembling and assessment very useful for their learning.

It is also worth mentioning that students' opinions about the benefits of portfolio assembling and assessment are in agreement with those manifested in Apple and Shimo 
(2004) and Martínez Lirola and Crespo (2009), since these three samples of learners considered that the main benefit is that portfolios are based on a daily-basis work, which from their point of view favours learning since it implies less pressure than having just one final exam as well as fostering the development of a more critical awareness towards the learning matters. On the other hand, being portfolios included in the evaluation system increases students' motivation since they think evaluation is more fair and learners have more chances to get better grades when compared to just being evaluated by a final exam.

Students' responses about disadvantages also bear a resemblance to previous research on the field (Apple and Shimo, 2004; Fernández Polo and Cal Varela, 2011; Martínez Lirola and Rubio, 2009; Pozo Llorente and García Lupión, 2006) since the students who took part in all these studies pointed out the fact that portfolio assembling takes up a lot of time, requires more effort, therefore it demands hard work, being sometimes difficult to keep up group work.

Regarding the methodology applied during the semester, most of our informants believed that it was appropriate to foster translation learning. These views concur with the findings obtained by Fernández Polo and Cal Varela (2011) in a study carried out in the subject of translation which seems to show that including portfolios in translation teaching and learning seems to be positive to foster learning.

Fernández Polo and Cal Varela's work also emphasizes the fact that students' are not completely satisfied with the percentage given to portfolio assessment in the final grade of the subject. Thus, their findings show that the majority of students found the weight originally allocated to the portfolio to be insufficient, and would welcome an increase to 40 or $50 \%$ of the final grade. This testifies to the students' profound awareness of the central role of the tool in the course, in their acquisition of the course contents and the attainment. This same view was shared by one of our students, and resembles the aforementioned learners' opinions on the most negative aspects of portfolio assembling i.e. being time-consuming, and effort requiring (Apple and Shimo, 2004; Fernández Polo and Cal Varela, 2011; Martínez Lirola and Rubio, 2009; Pozo Llorente and García Lupión, 2006). A possible means to solve this negative perception on portfolio assembling would be to assign a higher weight to portfolio evaluation or, otherwise, reduce the amount of tasks students should include in their portfolios.

\section{Conclusion}

This paper has reported students' beliefs on a pedagogical initiative consisting in the implementation of the student's portfolio in an undergraduate Spanish-English/EnglishSpanish translation course. We started by arguing that the new normative framework for the organisation of higher education in Europe implies that the teaching learning process should become an undertaking in which both students and teachers share responsibility for learning outcomes. This change is likely to affect evaluation, which must be understood as a dynamic process totally integrated in the teaching-learning 
process. The use of portfolios fits perfectly in the philosophy proposed by the EHEA because evaluating students in this way reinforces the idea that the central element in the new paradigm is the student and their learning process. For this reason, evaluation must be an accurate reflection of the activities carried out throughout the year. Therefore, the traditional exam is unable, by itself, to fulfil the needs of the EHEA model. Moreover, there should be a clear and direct relationship between the tools employed in evaluation and the results students obtain. Consequently, alternative ways of evaluation such as the portfolio reflect the learning process as a whole and consequently democratize the evaluation process.

This paper has also attempted to provide students' perspectives about the advantages, the disadvantages, and the learning efficacy of using a portfolio as an instrument for evaluation and learning. The results of this study corroborate those of studies conducted in Spain and abroad (Apple and Shimo, 2004; Fernández Polo and Cal Varela, 2011; Martínez Lirola and Rubio, 2009; Pozo Llorente and García Lupión, 2006), which show that students find the use of portfolios more beneficial than harmful to their learning outcomes, whether considered from a procedural or productive perspective.

Despite being a very helpful learning tool, the portfolio has some disadvantages from students' perspective. Most students considered the process of completing each task in the portfolio very time-consuming, which implies that it is not always possible to have the portfolio updated; moreover, they found it difficult to meet the other group members to prepare the activities that the group work entailed. Learners need specific, clear directions about what the instructor expects from the portfolio. Some learners, especially those accustomed to traditional testing methods of evaluation, may be frustrated when expected to set their own learning goals, to choose their own work for portfolio inclusion, and to reflect on their work or that of their peers. Despite these difficulties, students agreed that the experience gained and the results obtained were worth the effort.

The observed results of our experience of using the portfolio to learn translation at an undergraduate level are highly positive and extremely encouraging for the future. Despite the fact that our findings concur with those obtained by other researchers working with bigger samples, these data cannot be generalised since the sample analysed is not very wide (15 students) and the students are supposed to be interested in translation being it an optional subject they had personally chosen. Therefore, further research needs to be carried out with a wider number of informants in a core subject (e.g. English language) which is taught in several degrees (Primary Education, History and Geography. Spanish Language and Literature or Tourism) with a twofold objective: (a) test students' attitudes and beliefs on portfolio assessment, and (b) check if portfolio use involves students assuming new roles in the teaching-learning process, so that students can assume more responsibility and become active participants in the classroom to foster the development of their critical thinking skills, and therefore autonomous learning, which also implies that they have an active role in the teachinglearning process, is fostered. 


\section{References}

Apple, Matthew and Shimo, Etsuko (2004): "Learners to Teacher: Portfolios, please! Perceptions of Portfolio Assessment in EFL Classrooms." The Interface between Interlanguage, Pragmatics and Assessment: Proceedings of the 3rd Annual JALT PanSIG Conference.

<http://www.jalt.org/pansig/2004/HTML/AppleShimo.htm> (16/07/2012).

Baker, Mona (1998): “Translation Studies.” In Mona Baker, ed., Routledge Encyclopaedia of Translation Studies. London: Routledge, 277-281.

Baker, Mona (1996). "Professing Translation." The European English Messenger VI(1): 42.

Barberá, Elena (2005): "La evaluación de competencias complejas: la práctica del portafolio." Educere 31: 497-503.

Benson, Phil (2007): “Autonomy in language teaching and learning." Language Teaching, 40(1): 21-40.

Benson, Phil and Peter Voller (eds.)(1997): Autonomy and Independence in Language Learning. London: Longman.

Black, Paul and Dylan William (1998): “Assessment and Classroom Learning.” Assessment in Education 5(1): 7-74.

Brown, Sally and Angela Glasner (eds.)(1999): Assessment Matters in Higher Education Choosing and Using Diverse Approaches. Buckingham: Oxford University Press.

Canga Alonso, Andrés (2011): "El portafolio como recurso para la reflexión y la autoevaluación en alumnos con dificultades de aprendizaje." Porta Linguarum 16: 137153.

Carson, Lorna (2011): "Portfolio Learning in the English Language Classroom: What, Why and How in the Case of the European Language Portfolio." Ultimate Teacher, 2. ELTA, Albania.

<https://docs.google.com/file/d/0B51hZEXoRt0QjBHbU5OTnJUbi1aYUhxbkt3Q01wQ Q/edit?pli=1> (04/06/2012).

Cassany, Daniel (ed.)(2006): El Portfolio Europeo de las Lenguas y sus aplicaciones en el aula. Madrid: MEC (Colección Aulas de Verano).

Cotterall, Sarah and David Crabbe (eds.)(1999): Learner Autonomy in Language Learning: Defining the Field and Effecting Change. Bern: Peter Lang.

Crystal, David (1987): "Translating and Interpreting." In The Cambridge Encyclopedia of Language. New York: Cambridge University Press, 344-349.

Dam, Leni (1995): Learner Autonomy 3: From Theory to Classroom Practice. Dublin: Authentik.

Escobar, Cristina (2001). "La evaluación." In Luci Nussbaum and Mercé Bernaus, eds., Didáctica de las lenguas extranjeras en la educación secundaria. Madrid: Síntesis, 605639.

Fernández Polo, Francisco Javier and Mario Cal Varela (2011): "Learning Translation through the Use of Portfolios: Description of an Experience." @tic. revista d'innovació educativa 7. <http://ojs.uv.es/index.php/attic/article/view/1018/988> (30/05/2012).

Gardner, David (2011): Fostering Autonomy in Language Learning. Gaziantep: Zirve University. Retrieved from <http://ilac2010.zirve.edu.tr> (24/01/2013).

Little, David (2009): "The European Language Portfolio Where Pedagogy and Assessment Meet."〈http://www.coe.int/t/dg4/education/elp/elpreg/Source/Publications/ELP_pedagog y_assessment_Little_EN.pdf.> (20/05/2012). 
(2007): "Language Learner Autonomy: Some Fundamental Considerations Revisited." Innovation in Language and Teaching 1(1): 14-29.

(1991): Learner Autonomy 1: Definitions, Issues and Problems. Dublin: Authentik.

Martínez Lirola, M. (2012a): "Evaluating with a Portfolio in the European Higher Education Framework: an Example from English Studies." Revista Española de Lingüística Aplicada (RESLA) 25: 147-164.

(2012b): "Evaluation Proposal Based on the ECTS: Evaluating the Four Skills in a University Core Subject with a Portfolio'. Porta Linguarum 17: 189-201.

(2008a): "El uso del portfolio como herramienta metodológica evaluadora en el proceso de convergencia europea." Profesorado. Revista del curriculum y formación del profesorado 12(2). <http://www.ugr.es/ recfpro/rev122COL4.pdf> (01/07/2012).

_ (2008b): "Una propuesta de evaluación en el EEES. El uso del portfolio en una clase de idiomas." Porta Linguarum 9: 23-34.

Martínez Lirola, María and Eliecer Crespo (2007): "La evaluación en el marco del EEES: El uso del portfolio en Filología Inglesa." Red U. Revista de Docencia Universitaria 2. <http://revistas.um.es/redu/article/view/3351> (20/07/2012).

Martínez Lirola, María and Fernando Rubio (2009). "Students' Beliefs about Portfolio Evaluation and its Influence on their Learning Outcomes to Develop EFL in a Spanish Context." International Journal of English Studies 9 (1): 91-111.

Meeus, Will, Linda Van Looy and Peter Van Petegem (2006): "Portfolio in Higher Education: Time for a Clarificatory Framework. Educational Journal of Teaching and learning in Higher Education 17(2): 127-135.

Nida, Eugene and William D. Reyburn (1981): Meaning across Cultures. Orbis: New York.

Nunes, Alexandra (2004): "Portfolios in the EFL classroom: disclosing an informed practise." ELT Journal 58(4): 327-335.

Oxford. Rebecca L. (2011): Teaching and Researching Language Learning Strategies. Harlow: Longman.

O’Malley, J. Michael and Lorraine Valdez Pierce (1996): Authentic Assessment for English Language Learners. Reading, MA: Addison-Wesley.

Pérez Paredes, Pascual and Fernando Rubio (2005): "Testing and assessment." In Neil McLaren, Daniel Madrid and Antonio Bueno, eds., TEFL in Secondary Education. Granada: Universidad de Granada, 605-639.

Pozo Llorente, $\mathrm{M}^{\mathrm{a}}$ Teresa and Beatriz García Lupión (2006): "El portafolios del alumnado: una investigación-acción en el aula universitaria. Revista de Educación 34: 737-756.

Realising the European Higher Education Area Communiqué of the Conference of Ministers responsible for Higher Education (2003).

<http://www.bologna-berlin2003.de/pdf/Communique1.pdf> (10/05/2012).

Roca de Larios, Julio and Sonia López Serrano (2011): “Consideraciones prácticas sobre la elaboración de portafolios del estudiante: su aplicación al aprendizaje de la pronunciación del inglés." Didáctica. Lengua y Literatura 23: 349-367.

Sinclair, Barbara, Ian McGrath and Terry Lamb (eds.)(2000): Learner Autonomy, Teacher Autonomy: Future Directions. Harlow: Longman.

The Bologna Declaration on the European Space for Higher Education: An Explanation (1999). $<$ http://ec.europa.eu/education/policies/educ/bologna/bologna.pdf> (10/05/2012).

The European Higher Education Area -Achieving the Goals. Communiqué of the Conference of European Ministers Responsible for Higher Education (2005) http://www.bolognabergen2005.no/Docs/00-Main_doc/050520_Bergen_Communique.pdf (10/05/2012). 
Towards the European Higher Education Area Communiqué of the meeting of European Ministers in charge of Higher Education (2001). <http://www.bolognaberlin2003.de/pdf/Prague_communiquTheta.pdf> (10/05/2012).

Vygotsky, Lev V. (1978): Mind in Society. The Development of Higher Psychological Processes. Cambridge, MA: Harvard University Press.

Wright, W. Alan, Peter T. Knight and Natalie Pomerleau (1999): "Portfolio People: Teaching and Leaning Dossiers and Innovation in Higher Education." Innovative Higher Education 24(2): 89-103.

Yan, Nae-Don (2003): "Integrating Portfolios into Learning Strategy-Based Instruction for EFL College Students." IRAL 41: 293-317.

\section{APPENDIX 1}

Questionnaire to analyse the main positive and negative aspects of portfolio use for students in the subject Translation Spanish-English/English Spanish (adapted from Martínez Lirola and Rubio, 2009: 111).

(THIS SURVEY IS ANONYMOUS)

1. Are you happy having been evaluated with a portfolio? Why?

2. What are the main positive aspects that you observed in the use of a portfolio as a student?

3. What are the main negative aspects that you observed in the use of a portfolio as a student?

4. Would you recommend a different way of evaluating this course? If yes, please, explain.

5. Do you think that the methodology of this course has been appropriate? Why?

6. Do you think that the methodology of this course fosters learning?

7. What would you change about the methodology of this course?

8. Would you recommend this course to other students? Justify your answer. 